\title{
Large-Scale Aerial Images Capture Details of Invasive Plant Populations
}

\author{
Dana Blumenthal, ${ }^{1}$ D. Terrence Booth, ${ }^{2}$ Samuel E. Cox, ${ }^{3}$ and Cara E. Ferrier ${ }^{4}$ \\ Authors are ${ }^{1}$ Ecologist, ${ }^{2}$ Rangeland Scientist, and ${ }^{3}$ Biological Science Technician, USDA-ARS Rangeland Resources Research Unit, High Plains Grassland \\ Research Station, Cheyenne, WY; and ${ }^{4}$ Assistant Manager of Field Science Support, Raytheon Polar Services, Centennial, CO.
}

\begin{abstract}
Satellite and high-altitude aerial remote sensing have been used to measure dense infestations of invasive weeds over very large areas but have limited resolution and cannot be used to detect sparsely distributed weeds. Ground-based methods have provided detailed measurements of invasive weeds but can measure only limited areas. Here we test a novel approach that uses a lightweight airplane, flying at $72 \mathrm{~km} \cdot \mathrm{h}^{-1}$ and $100-\mathrm{m}$ altitude, to rapidly collect high-resolution images over relatively large areas. We obtained 1987 images, each representing $48.5 \mathrm{~m}^{2}$ of mixed-grass prairie with 2-mm resolution (ground sample distance). From these images we were able to reliably measure small patches and even individual plants of the invasive forb Dalmatian toadflax (Linaria dalmatica [L.] P. Mill.). Ground-based measurements of aboveground toadflax biomass were highly correlated $\left(R^{2}>0.93\right)$ with point-intercept and visual-estimate cover measurements from aerial images. The time required to analyze images ranged from 4 to 45 seconds for presence/absence data and from 1 to 6 minutes for cover data. Toadflax was present in 795 of 1987 images but exceeded 1\% cover in only 99 images. Given the observed variation among images in toadflax cover, at least 400 images were needed to precisely estimate the mean toadflax cover of $0.2 \%$. These results suggest that such high-resolution aerial imagery could be used to obtain detailed measurements of many invasive weed populations. It may be most useful for identifying incipient weed infestations and expanding the scale at which population-level attributes of weed populations can be effectively measured.
\end{abstract}

\section{Resumen}

Los satélites y los sensores remotos de gran altitud han sido usados para medir densas infestaciones de malezas invasoras en grandes áreas, pero tienen una resolución limitada y no pueden ser usados para detectar las malezas distribuidas dispersamente. Los métodos terrestres han suministrados mediciones detalladas de las malezas invasoras, pero solo pueden medir áreas limitadas. Probamos un método novedoso que utiliza un avión ligero volando a $72 \mathrm{~km} \cdot \mathrm{h}^{-1}$ y 100 -m altitud para colectar en forma rápida imágenes de alta resolución en áreas relativamente grandes. Obtuvimos 1987 imágenes con una resolución de $2 \mathrm{~mm}$ (distancia de la muestra terrestre), cada una representando $48.5 \mathrm{~m}^{2}$ de una pradera de zacates mixtos. A partir de estas imágenes fuimos capaces de medir confiablemente pequeños parches, y aun plantas individuales, de la especie invasora "Dalmatian toadflax" (Linaria dalmatica [L.] P. Mill.). Las mediciones terrestres de la biomasa aérea del "Toadflax" estuvieron altamente correlacionadas $\left(R^{2}>0.93\right)$ con las estimaciones de cobertura obtenidas de las imágenes aéreas con la línea de intercepción de puntos y la estimación visual. El tiempo requerido para analizar las imágenes varió de 4 a 5 segundos para los datos de presencia/ausencia y de 1 a 6 minutos para los datos de cobertura. El "Toadflax" estuvo presente en 795 de 1987 imágenes, pero excedió el 1\% de la cobertura en solo 99 imágenes. Dada la variación de cobertura del "Toadflax" observada entre imágenes, al menos 400 imágenes se necesitaron para estimar precisamente la media de cobertura de $0.2 \%$ del "Toadflax." Estos resultados sugieren que estas imágenes aéreas de alta resolución pueden ser usadas para obtener mediciones detalladas de muchas poblaciones de especies invasoras. El método puede ser más útil para identificar infestaciones incipientes de maleza y expandir la escala a la cual los atributos a nivel de población pueden ser medidos efectivamente.

Key Words: Dalmatian toadflax, Linaria dalmatica, lightweight aircraft, monitoring, remote sensing

\section{INTRODUCTION}

Invasive weeds are now recognized as a significant threat to productivity and biological diversity, leading to an urgent need to both understand and manage problematic invaders (Vitou-

Mention of a proprietary product does not constitute a guarantee or warranty of the product by USDA or the authors and does not imply its approval to the exclusion of other products that may be suitable.

At the time of the research, C. Ferrier was a Biological Science Technician at the USDA-ARS Rangeland Resources Research Unit.

Correspondence: Dana Blumenthal, USDA-ARS Rangeland Resources Research Unit, Crops Research Laboratory, 1701 Center Ave, Fort Collins, CO 80521. Email: dana.blumenthal@ ars.usda.gov

Manuscript received 14 December 2006; manuscript accepted 27 May 2007. sek 1997; Duncan and Clark 2005). The large geographical scale of plant invasions not only contributes to this urgency but also presents challenges of measurement. Because invasive species success varies tremendously among environments, understanding the factors that drive invasion requires largescale studies (D'Antonio et al. 2004). Such problems are compounded for managers who must locate and control invasive species over large areas and monitor the effects of control strategies over time (Ries et al. 2004).

Remote sensing has the potential to greatly reduce the time and resources needed to measure invasive species across large scales. Both satellite and aerial imagery have been successfully used to map invasive species within watersheds and even regions (Everitt et al. 1995, 1996; Anderson et al. 1996; Lass et 
al. 2005; Bradley and Mustard 2006). Successful use of these methods, however, typically requires dense populations of species with unique growth patterns or spectral qualities (Turner et al. 2003; Lass et al. 2005). Considerably more detail can be obtained using ground-based remote sensing, which is commonly used to map weeds for precision herbicide application (Shaw 2005) or to measure bare ground and vegetative cover (Booth et al. 2005; Luscier et al. 2006; for a review of authors publishing on the subject between Cooper 1924 and Bennett et al. 2000, see Booth et al. 2004). However, it is often impractical to obtain ground-based images over large areas (i.e., $>200 \mathrm{ha}$ ) or in rough terrain.

Here we test a novel approach to measure invasive weed populations using 2-mm ground sample distance (GSD) aerial imagery. This remote sensing method allows for rapid collection of high-resolution images over rough terrain, potentially filling a niche between ground-based imagery and lower-resolution aerial or satellite imagery. The use of aerial imagery with resolutions as fine as 1-mm GSD is being used to measure bare ground in rangeland systems (Booth and Cox 2006; Seefeldt and Booth 2006). The use of this very large scale aerial (VLSA) imagery in these applications decreases the cost of resource monitoring primarily by reducing the amount of ground travel time required for adequate monitoring. Recent reports that similar approaches can be used to identify squarrose knapweed (Centaurea virgata Lam. ssp. squarrosa Gugl.) suggest that such methods are also promising for studying and monitoring invasive species (Hardin and Jackson 2005). Here we present the first test of the accuracy of VLSA imagery in measuring weed populations. Our objective in this study was to test the use of VLSA imagery for measuring populations of a common but, at our study site, sparsely distributed weed, Linaria dalmatica (L.) P. Mill. ssp. dalmatica (Dalmatian toadflax). Dalmatian toadflax (hereafter toadflax) is a perennial forb that spreads by both seeds and horizontal roots and is commonly found both in disturbed areas and in intact grassland, shrubland, and open forest ecosystems (Vujnovic and Wein 1997). Native to Eurasia, toadflax is now widespread in North America and is particularly common in the western United States and Canada.

\section{MATERIALS AND METHODS}

\section{Experimental Design and Study Site}

To test the accuracy of toadflax measurements taken from aerial images, we selected 50 images (from a set of 2049 aerial images, each representing $48.5 \mathrm{~m}^{2}$ of mixed-grass prairie) for ground-truthing. Images were selected to include a range of toadflax densities, including images containing no apparent toadflax. Images of poor quality, generally due to motion blur $(0.5 \%$ of the 2,049 images $)$, were omitted from consideration. Images containing fences $(2.4 \%)$ were also omitted; however, this was incidental to the use of the images in a second study and does not reflect difficulty in using images containing fences. Cover estimates from aerial images were then regressed on aboveground biomass measurements from the areas depicted in the images. To estimate the time required for visual-estimate and point-sampling cover measurements from aerial images, we timed each method on a second set of 10 images, spanning the full range of toadflax cover observed in the 1987 good-quality images.

The study was conducted at the High Plains Grassland Research Station, Cheyenne, Wyoming, July-August 2003. The climate at this site is semiarid, with an average annual precipitation of $458 \mathrm{~mm}$ (1977-2005). January-June precipitation in 2003 was $219 \mathrm{~mm}$. Images were collected within a set of annually grazed pastures, comprising a total of 400 ha of native northern mixed-grass prairie. Vegetation was dominated by grasses, including western wheatgrass (Pascopyrum smithii [Rydb.] A. Love), needle-and-thread (Stipa comata Trin \& Rupr.), and blue grama (Bouteloua gracilis [H.B.K.] Lab. Ex Steud) but also included a wide variety of forbs and subshrubs. Primary soil series are Ascalon and Altvan sandy loams (Stevenson et al. 1984). Grazing timing and intensity were consistent for 8 years prior to this study but varied among pastures, which were grazed at either moderate $(6.29 \mathrm{ha} \cdot$ cowcalf pair $\left.{ }^{-1}\right)$ or heavy $\left(5.14\right.$ ha $\cdot$ cow-calf pair $\left.{ }^{-1}\right)$ stocking rates.

\section{Aerial Image Collection}

Our methods followed those previously described (Booth and Cox 2006; Seefeldt and Booth 2006). We used an 11.1megapixel Canon EOS 1Ds digital color camera mounted in a $225-\mathrm{kg}$ (empty weight), piloted fixed-wing aircraft flown at $72 \mathrm{~km} \cdot \mathrm{h}^{-1}$ ground speed $100 \mathrm{~m}$ above ground level to obtain imagery with approximately $2-\mathrm{mm}$ resolution, or GSD. The camera was connected to a vibration-resistant computer (Image Labs, Bozeman, MT) via an IEEE-1394 (Fire Wire) interface cable allowing images to be stored directly on a 24 gigabyte hard drive. We equipped the camera with a Canon 300-mm, f/2.8 autofocus, image-stabilizing lens. A $1.4 \times$ teleconverter was also added to give the equivalent of a 420$\mathrm{mm} \mathrm{f/3.5} \mathrm{lens.} \mathrm{Shutter} \mathrm{speed} \mathrm{was} \mathrm{manually} \mathrm{set} \mathrm{for} \mathrm{1/}$ 4000 second, ISO was set at 400-500 ISO, and automatic override ("safety shift") was enabled to slow the shutter in the event of insufficient light for proper exposure. The camera was automatically triggered by an aerial survey system (Track'Air, Oldenzaal, The Netherlands). The flight plan for the aerial survey system was created by using Didger II (Golden Software, Golden, CO) to extract GPS coordinates for target points from a digitized raster graphic of the study site. The coordinates were then entered into the flight plan creator in the Track'Air software, resulting in real-time visual navigation to sequential targets for the pilot. A Riegl LD90-3100VHS-FLP laser distance meter (Riegl USA, Inc., Orlando, FL) was mounted near the camera with a $\pm 1-\mathrm{m}$ readout displayed to the pilot on a laptop screen so airplane altitude above ground level could be maintained at approximately $100 \mathrm{~m}$. We acquired 2049 2-mm GSD aerial images on 22-25 July 2003. Several flight plans were pieced together to achieve the closest possible spacing of photographs given a sustainable frame rate of 1 image every 3 seconds. Individual images, each representing a ground area of approximately $8.5 \times 5.7 \mathrm{~m}$ (but varying because of airplane flight altitude), were taken every $70 \mathrm{~m}$ on east-west flight lines spaced $30 \mathrm{~m}$ north to south. Coordinates for every image trigger were automatically recorded. Images were acquired in Canon raw format and converted to 8-bit TIFF format for analysis. 


\section{Toadflax Measurements}

Ground-based measurements of toadflax mass and stem density were taken between 29 July and 15 August 2003. Because of the high resolution of the images, we were able to identify the $8.5 \times 5.7 \mathrm{~m}$ area depicted in each of the 50 selected images using a combination of GPS coordinates recorded at the time the image was taken and patterns of vegetation and soil. After staking the corners of a plot depicted in an image, we counted stems and harvested all aboveground toadflax within the plot. Harvested material was dried at $60^{\circ} \mathrm{C}$ for 3 days prior to weighing. Of the 50 images for which we collected groundbased data, 5 were used to help us learn to identify toadflax in the images. The remaining 45 images were used for groundtruthing to test the correlation of image-based cover measurements with toadflax mass.

Aerial image analysis was limited to visual measurements of toadflax cover. Although we had intended to count toadflax stems in the images, in order to compare ground and aerial image measurements using the same metric, it proved too difficult to visually separate stems and branches. Automated analyses were precluded by the presence of plant species with leaf and flower color similar to that of toadflax. For the 45 images used for ground-truthing, we measured cover using both point-sampling and visual-estimate methods. Images were displayed at $66 \%$ or $100 \%$ magnification in Photoshop Elements (Adobe Systems Inc., San Jose, CA). Point sampling was conducted by superimposing 1-pixel-thick digital grids over aerial images and counting the number of intersections (points) on the grids that covered toadflax. To determine the number of points per image needed to accurately measure toadflax cover, multiple grid scales were used, including grids with 126, 504, 2 072, and 8288 intersections per image. Visual estimates were conducted with the aid of a 1-pixel-thick digital grid that divided each image into squares similar in size to sections of toadflax plants, each image containing a total of 1350 squares. For the remaining 1937 images, only visual cover estimates were used.

To determine the time needed for image analysis, 10 representative images, covering the full range of toadflax cover values, were analyzed and closely timed using both pointsampling and visual-estimate methods. Point sampling was conducted using 504 intersections per image, the least number of points required to get a close correlation with toadflax mass. Weighted averages of analysis time by cover class were calculated and used to estimate the amount of time required to analyze the full 1987 images.

\section{Data Analysis}

Regressions of toadflax cover on mass were conducted using JMP version 5 (SAS Institute 2002). Point-sampling measurements from each of the 4 grid scales and the visual estimates were regressed against toadflax biomass $(n=45)$. To reduce nonnormality and heteroscedasticity, all variables were $\log _{10}$ transformed prior to analysis. Because zeros were present for all variables, the smallest positive value observed for each variable was added to each value for that variable prior to transformation. As these transformations also reduced nonlinearity, we were able to use simple linear regressions in all cases. To determine the number of images needed to precisely measure the mean cover of toadflax over our study area, we calculated means and confidence intervals for 1978 randomly selected subsets of images, ranging from $n=10$ to $n=1987$ (Software written with Bob Berryman Consulting, Boulder, $\mathrm{CO})$.

\section{RESULTS}

Although a variety of yellow-flowering forbs were present in the aerial images, including hairy false golden aster (Heterotheca villosa [Pursh] Shinners) and low sunflower (Helianthus pumilus Nutt.), with practice we were able to reliably identify toadflax. In general, a combination of traits were used to positively separate toadflax from similar forbs, including leaf size, color, and shape; flower size; and stem height (often judged from shadows), shape, and distribution (Fig. 1). Although the 2-mm GSD of these photos appeared to provide enough resolution to measure cover, more detailed measurements, such as leaf or flower number, would probably require finer resolution.

Point-sampling cover measurements from aerial images were closely correlated $\left(R^{2}=0.93, n=45\right)$ with toadflax mass when 8288,2072 , or 504 points were sampled on each image (Figs. 2A and 2B). With only 126 points per image, however, the cover-mass relationship weakened considerably, apparently because this method of cover estimation failed to identify some smaller toadflax infestations $\left(R^{2}=0.74, n=45\right.$; Fig. 2C). Despite the close correlation between cover and mass with 504 points per image, some images containing very small patches of toadflax were measured as having no toadflax using this intensity of point sampling (Fig. 2B). The same problem did not occur when 2072 or 8288 points per image were sampled. Visual estimates were also highly correlated with mass $\left(R^{2}=0.94, n=45\right.$; Fig. 2D).

The time required for image analysis depended on the type of measurement and the toadflax cover in the image. For presence/ absence measurements, determining presence takes between 4 and 15 seconds, while determining absence in images with no toadflax could take as long as 45 seconds. Determining presence/absence for the full 1987 images is estimated to require 10.1 hours (18.3 seconds per image weighted average). Less dense weed infestations would likely take longer. Conversely, measuring cover was faster when there was little toadflax cover. Time required for visual estimates ranged from 1 minute at $1 \%$ cover to 6 minutes at $8 \%$ cover, while time required for point sampling (with 504 points) ranged from 2 minutes at $1 \%$ cover to 4 minutes at $8 \%$ cover. Weighting the time per image by the heavy preponderance of low-cover images, the visual-estimate and point-sampling methods are estimated to have required 16.8 hours ( 77 seconds per image) and 26 hours (117 seconds per image), respectively, for the 788 images containing toadflax. Note that these estimates do not include time required to learn to identify toadflax in images or to convert, organize, and store images.

Analysis of the full data set revealed that toadflax was relatively common throughout the study site, occurring in $40 \%$ of the 1987 images. Toadflax cover was generally low, however, exceeding $1 \%$ cover in only $5 \%$ of the images. Maximum toadflax cover was $8.7 \%$. Mean toadflax cover for 


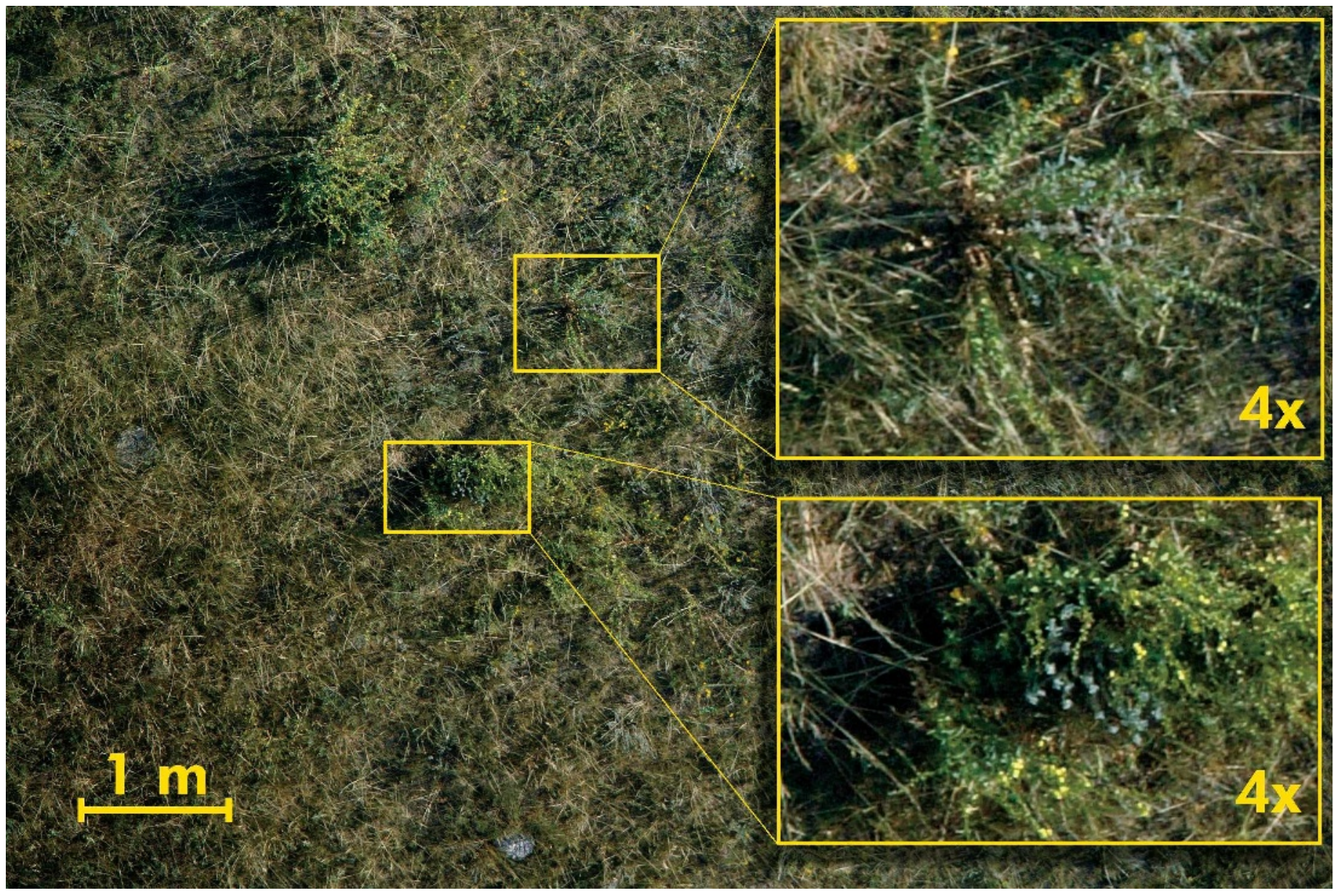

Figure 1. Digital aerial image of mixed-grass prairie containing multiple patches of toadflax. Upper inset shows an individual toadflax plant with 6 stems. Lower inset shows a dense patch of toadflax. Both insets also contain Artemisia frigida Willd. (prairie sagewort), with lighter graygreen foliage.

the entire study area was $0.20 \% \pm 0.058 \mathrm{CI}(n=1987)$. Thus, with sampling intensity similar to that used here, we would expect to be able to detect changes in toadflax cover larger than $0.058 \%$ (29\% of the mean). Testing how the confidence interval depended on sample size, we found that interval width decreased rapidly until approximately 400 images (making up $0.5 \%$ of the study area) were sampled (Fig. 3). Thus, we would expect that capturing a minimum of 400 aerial images in a future flight would allow changes in toadflax cover greater than $0.1 \%$ cover $(50 \%$ of the mean) to be detected.

\section{DISCUSSION}

The close relationship we observed between cover measurements from aerial images and ground-based biomass measurements demonstrates that VLSA imagery can be used to accurately measure invasive weed infestations (Fig. 2). In the present study, VLSA imagery was effective in measuring a common (present in $40 \%$ of samples) but sparsely distributed (generally less than $1 \%$ cover) invader. Such measurements would not have been possible using lower-resolution aerial or satellite imagery and would likely have been considerably more difficult using ground surveys. To the degree that these results apply to other species and ecosystems, VLSA imagery may fill an important niche between ground-based remote sensing and smaller-scale aerial imagery or satellite-based remote sensing.

From a research perspective, the level of detail in the images, together with the relative ease of acquiring the images, may allow for measurement of population level characteristics over larger areas than previously possible. The spatial resolution of conventional aerial images ranges from 0.25 - to 4-m GSD, while that of satellite images ranges from 0.6- to 80-m GSD (Digital Globe Inc., Longmont, CO; Lass et al. 2005). By contrast, the VLSA system used for this study resulted in 2-mm GSD. Such fine resolution made it possible to detect and measure not only dense patches but also isolated individual plants of toadflax.

In addition to its advantages, this method has several important limitations. First, it is a method for systematically subsampling a landscape rather than obtaining complete coverage of a landscape. This problem arises from limits to data transfer speed and data storage. In the present study, for example, although our 2049 images made up a total ground area of $99377 \mathrm{~m}^{2}$, this represented only $2.4 \%$ of the total study area. Consequently, VLSA imagery cannot be used to create very high resolution (2-mm GSD) maps of weed populations for entire landscapes. Rather, it allows users to map weed 


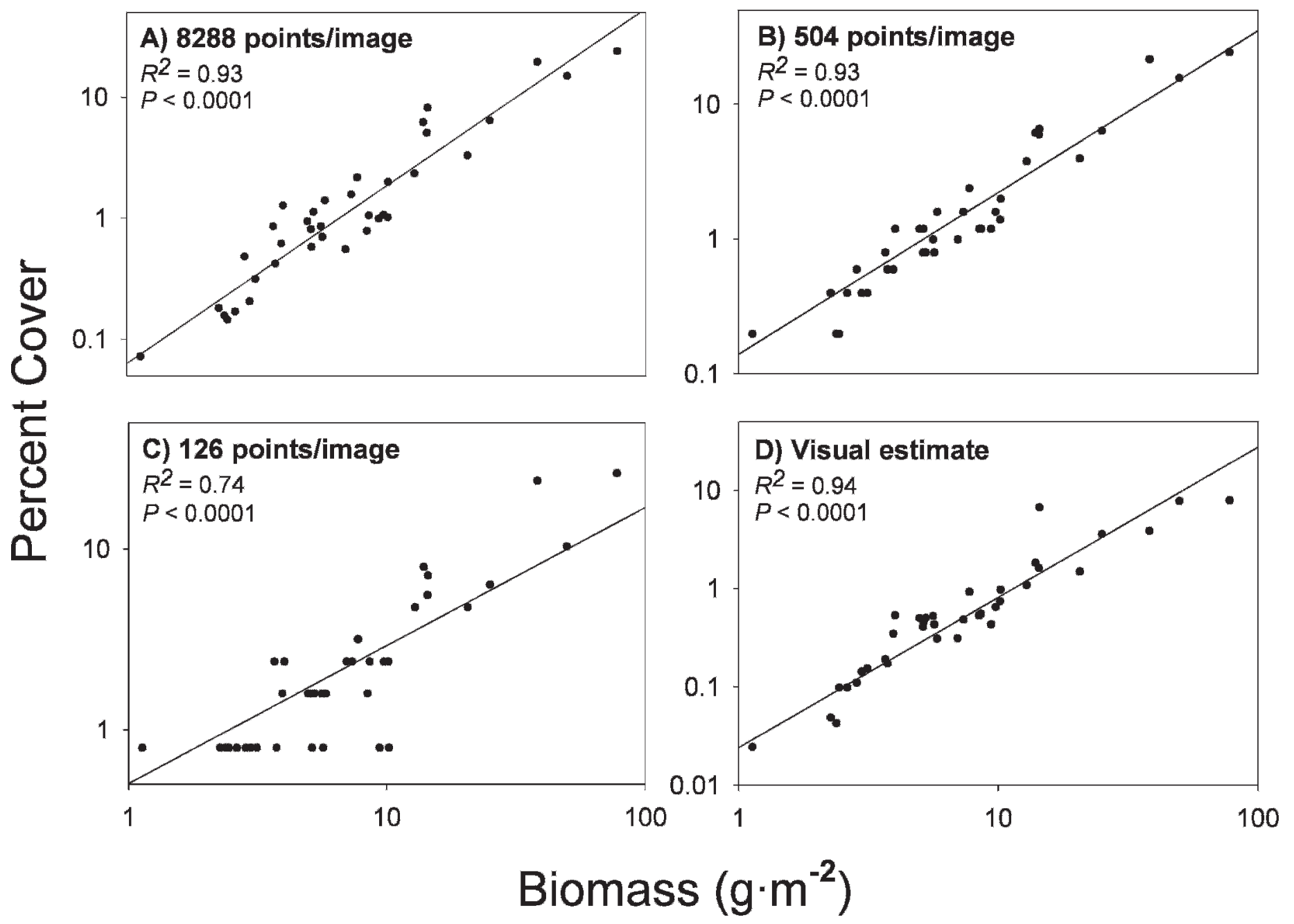

Figure 2. Regression of aerial image estimates of percent toadflax cover on ground-based aboveground toadflax biomass measurements. A close relationship is obtained using point sampling with $\mathbf{A}, 8288$ and $\mathbf{B}, 504$, but not $\mathbf{C}, 126$ points per image. D, Visual cover estimates from aerial images are also closely correlated with biomass. All data was $\log _{10}$ transformed to increase homoscedasticity, normality, and linearity. Graphs show backtransformed data presented on $\log _{10}$-transformed axes. Differences in the lower bounds of the y-axes reflect differences in the lowest toadflax cover detected by each method. Note that the point in the lower left-hand corner of each graph is in fact 5 points, representing images that contained no toadflax $(N=45)$.

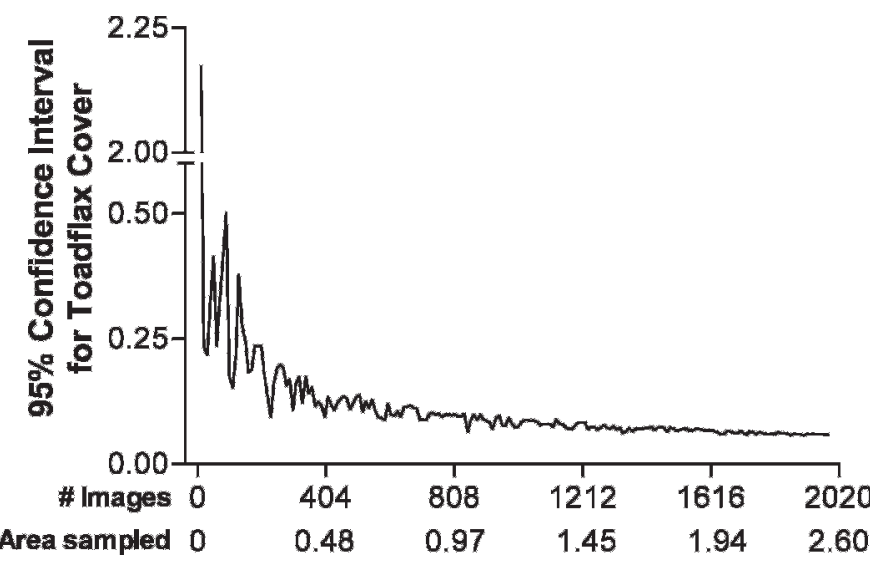

Figure 3. Sample number (also represented as a \% of the total study area) and resulting 95\% confidence intervals for mean toadflax cover of the entire study area as measured by visual cover estimates. patches within individual images $\left(48.5 \mathrm{~m}^{2}\right)$ or at large scales, with the level of detail determined by the intensity of sampling. A second limitation is that it is not possible to repeatedly measure the same exact locations with the equipment configuration described here. Although images can be repeatedly collected from the same GPS coordinates, small differences in the angle of the plane when the image is taken result in ground locations that can vary by several meters. Thus, although VLSA imagery can be used to detect changes over time by repeatedly subsampling large areas, detecting change at particular sample locations is quite difficult.

The utility of VLSA imagery for measuring weed infestations depends on the objectives, the weed species of interest, and the plant communities within which the weeds are present. VLSA imagery appears to be particularly well suited for accurately sampling individuals or small populations at landscape scales. In this study we successfully measured a relatively tall, distinctly shaped but not distinctly colored weed within a semiarid grassland that included few plants that could 
obscure the weed of interest. For smaller or less distinct species, including many grasses, positive identification might not be possible. Conversely, species with distinct colors at the time of image collection (e.g., Anderson et al. 1996; Everitt et al. 1996) or the addition of hyperspectral sensors (Lass et al. 2005; Ge et al. 2006) might allow for automated image analysis, greatly increasing the number of samples that could be collected and processed.

\section{MANAGEMENT IMPLICATIONS}

Difficulty in accurately measuring the distribution and abundance of invasive species can preclude both effective management and effective monitoring of management results. This work demonstrates that VLSA imagery can be used to obtain more accurate estimates of weed populations within particular pastures or watersheds. An advantage of the digital format is that it allows large numbers of images (samples) to be processed quickly, relative to the time requirement for ground sampling. This makes high statistical power a practical objective (Fig. 3). Statistical inferences about characteristics of the sampled area can give greater confidence than is usually achieved with ground-based methods for landscape-sized areas. For Dalmatian toadflax at our study site, the precision of the overall population estimate increased with sample size, but the degree of increase was slight beyond 400 samples (covering $0.5 \%$ of the study area), suggesting that this would be an appropriate sampling intensity (Fig. 3). It is important to note, however, that the appropriate sampling protocol will depend strongly on the distribution of the invasive species. Toadflax was relatively common at our study site. Measuring less evenly distributed invasive species could require considerably higher sampling intensity.

Identifying incipient weed invasions can allow managers to control invasions before they become too large (Hulme 2006). Finding such invasions is difficult, however, requiring extremely high sampling intensity. The VLSA images are well suited for identifying both small patches and low densities of invasive species. Furthermore, although measuring cover from VLSA images was time consuming, we found that presence/absence data could be collected very quickly (18 seconds per image). Thus, large numbers of images might be efficiently processed either with automated image analysis, if target species have distinctive colors or shapes, or manually, if only presence/ absence data are collected.

\section{ACKNOWLEDGMENTS}

Many thanks to Alicia Davisson, Justin Derner, Erik Hardy, Joe Nance, and Steve Tekell for assistance with data collection and analysis. Raymond Hunt, Matthew Rinella, Lewis Ziska, and 2 anonymous reviewers provided many helpful comments on earlier versions of this paper.

\section{LITERATURE CITED}

Anderson, G. L., J. H. Everitt, D. E. Escobar, N. R. Spencer, and R. J. Andrascik. 1996. Mapping leafy spurge (Euphorbia esula) infestations using aerial photography and geographic information systems. Geocarto International 11:81-89.
Bennett, L. T., T. S. Judd, And M. A. AdAms. 2000. Close-range vertical photography for measuring cover changes in perennial grasslands. Journal of Range Management 53:634-641.

Booth, D. T., AND S. E. Cox. 2006. Very-large scale aerial photography for rangeland monitoring. Geocarto International 21:27-34.

Booth, D. T., S. E. Cox, C. Fifield, M. Phillips, and N. Williamson. 2005. Image analysis compared with other methods for measuring ground cover. Arid Land Research and Management 19:91-100.

Booth, D. T., S. E. Cox, M. Louhaichi, and D. E. Johnson. 2004. Technical note: lightweight camera stand for close-to-earth remote sensing. Journal of Range Management 57:675-678.

Bradley, B. A., AND J. F. Mustard. 2006. Characterizing the landscape dynamics of an invasive plant and risk of invasion using remote sensing. Ecological Applications 16:1132-1147.

Cooper, W. S. 1924. An apparatus for photographic recording of quadrats. Journal of Ecology 12:317-321.

D’Antonio, C. M., N. E. Jackson, C. C. Horvitz, and R. Hedberg. 2004. Invasive plants in wildland ecosystems: merging the study of invasion processes with management needs. Frontiers in Ecology and the Environment 2:513-521.

DunCAN, L., AND J. K. CLARK. 2005. Invasive plants of range and wildlands and their environmental, economic, and societal impacts. Lawrence, KS: Weed Science Society of America. $222 \mathrm{p}$.

Everitt, J. H., G. L. Anderson, D. E. Escobar, M. R. Davis, N. R. Spencer, and R. J. ANDRASCIK. 1995. Use of remote sensing for detecting and mapping leafy spurge (Euphorbia esula). Weed Technology 9:599-609.

Everitt, J. H., D. E. Escobar, M. A. Alaniz, M. R. Davis, and J. V. Richerson. 1996. Using spatial information technologies to map Chinese tamarisk (Tamarisk chinensis) infestations. Weed Science 44:194-201.

Ge, S., J. Everitt, R. Carruthers, P. Gong, and G. Anderson. 2006. Hyperspectral characteristics of canopy components and structure of phenological assessment of an invasive weed. Environmental Monitoring and Assessment 120:109-126.

Hardin, P. J., AND M. W. Jackson. 2005. An unmanned aerial vehicle for rangeland photography. Rangeland Ecology and Management 58:439-442.

HuLme, P. E. 2006. Beyond control: wider implications for the management of biological invasions. Journal of Applied Ecology 43:835-847.

Lass, L. W., T. S. Prather, N. F. Glenn, K. T. Weber, J. T. Mundt, and J. Pettingilll. 2005. A review of remote sensing of invasive weeds and example of the early detection of spotted knapweed (Centaurea maculosa) and babysbreath (Gypsophila paniculata) with a hyperspectral sensor. Weed Science $53: 242-251$

Luscier, J. D., W. L. Thompson, J. M. Wilson, B. E. Gorham, and L. D. Dragut. 2006. Using digital photographs and object-based image analysis to estimate percent ground cover in vegetation plots. Frontiers in Ecology and the Environment 4:408-413.

Ries, P., M. E. Dix, M. Ielmini, and D. Thomas. 2004. National strategy and implementation plan for invasive species management. Washington, DC: US Department of Agriculture, Forest Service. FS-805. 17 p.

SAS InStitute. 2002. JMP statistics and graphics guide. Version 5. Cary, NC: SAS Institute. $707 \mathrm{p}$.

Seefeldt, S. S., AND D. T. Booth. 2006. Measuring plant cover in sagebrush steppe rangelands: a comparison of methods. Environmental Management 37:703-711

Shaw, D. R. 2005. Remote sensing and site-specific weed management. Frontiers in Ecology and the Environment 3:526-532.

Stevenson, A., R. E. Baumgartner, and G. E. Schuman. 1984. High plains grassland research station, detailed soil survey. Cheyenne, WY: USDA Agricultural Research Service. 1-84/1C/3.62. 99 p.

Turner, W., S. Spector, N. Gardiner, M. Fladeland, E. Sterling, and M. Steininger. 2003. Remote sensing for biodiversity science and conservation. Trends in Ecology and Evolution 18:306-314.

Vitousek, P. M. 1997. Introduced species: a significant component of humancaused global change. New Zealand Journal of Ecology 21:1-16.

Vujnovic, K., And R. W. Wein. 1997. The biology of Canadian weeds 106. Linaria dalmatica (L.) Mill. Canadian Journal of Plant Science 77:483-491. 